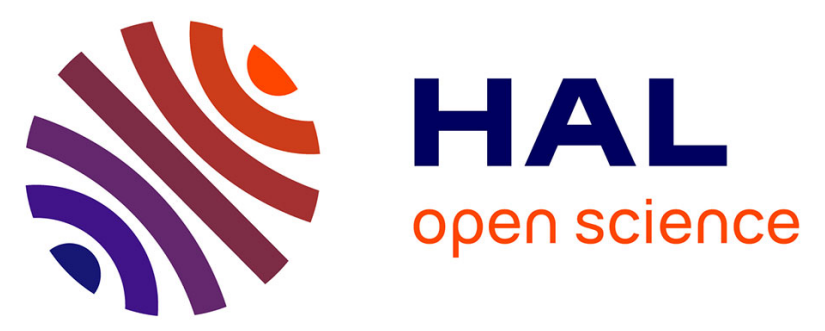

\title{
Impact of Biofield Treatment on Spectroscopic and Physicochemical Properties of p-Nitroaniline
}

Mahendra Kumar Trivedi, Alice Branton, Dahryn Trivedi, Gopal Nayak, Khemraj Bairwa, Snehasis Jana

\section{- To cite this version:}

Mahendra Kumar Trivedi, Alice Branton, Dahryn Trivedi, Gopal Nayak, Khemraj Bairwa, et al.. Impact of Biofield Treatment on Spectroscopic and Physicochemical Properties of p-Nitroaniline. Insights in Analytical Electrochemistry, 2015, 1 (1). hal-01435927

\section{HAL Id: hal-01435927 \\ https://hal.science/hal-01435927}

Submitted on 16 Jan 2017

HAL is a multi-disciplinary open access archive for the deposit and dissemination of scientific research documents, whether they are published or not. The documents may come from teaching and research institutions in France or abroad, or from public or private research centers.
L'archive ouverte pluridisciplinaire HAL, est destinée au dépôt et à la diffusion de documents scientifiques de niveau recherche, publiés ou non, émanant des établissements d'enseignement et de recherche français ou étrangers, des laboratoires publics ou privés.

\section{(c)(1)}

Distributed under a Creative Commons Attribution| 4.0 International License 
DOI: $10.21767 / 2470-9867.100002$

\section{Impact of Biofield Treatment on Spectroscopic and Physicochemical Properties of p-Nitroaniline}

Mahendra Kumar Trivedi ${ }^{1}$, Alice Branton ${ }^{1}$, Dahryn Trivedi ${ }^{1}$, Gopal Nayak", Khemraj Bairwa² and Snehasis Jana ${ }^{2}$

1 Trivedi Global Inc., 10624 S Eastern Avenue Suite A-969, Henderson, NV 89052, USA

2 Trivedi Science Research Laboratory Pvt. Ltd., Hall-A, Chinar Mega Mall, Chinar Fortune City, Hoshangabad Rd., Bhopal, Madhya Pradesh, India

\section{Corresponding author: Snehasis Jana}

”publication@trivedisrl.com

Trivedi Science Research Laboratory Pvt. Ltd., Hall-A, Chinar Mega Mall, Chinar Fortune City, Hoshangabad Rd., Bhopal-462 026, Madhya Pradesh, India.

Tel: +9175 56660006

Citation: Trivedi MK, Branton A, Trivedi $D$, et al. Impact of Biofield Treatment on Spectroscopic and Physicochemical Properties of p-Nitroaniline. Insights Anal Electrochem. 2015, 1:1. 


\section{Introduction}

Aromatic amines are very important in biology and chemical industry. Particularly aniline and its derivatives are being used as antioxidants, and in production of dyes and pesticides [1,2]. Additionally, the aromatic amines are also used as intermediate in the synthesis of several pharmaceutical drugs including acetaminophen, nadifloxacin, difloxacin, sarafloxacin, flumequin, cisapride, bicalutamide, brequinar, sorbinil etc. $[3,4]$. Some of para (p) substituted anilines have local anesthetic property, wherein amino group plays an important role in the interaction with respective receptor. $p$-Nitroaniline or 4-nitroaniline $\left(\mathrm{C}_{6} \mathrm{H}_{6} \mathrm{~N}_{2} \mathrm{O}_{2}\right)$ is one of the important compounds of this class [2]. It is a bright yellow powder with a faint ammonia-like odor. It is mainly used as an intermediate for the synthesis and preparation of several antioxidants, antiseptic agents, medicines for poultry and other pharmaceutical products [5]. Diazo product of this compound can be used for the production of azo dye in the textile industry. Some other chemical intermediates like $p$-phenylenediamine, 2-chlor4-nitroaniline, 2,6-dichloro-4-nitroanilen etc. are also prepared using $p$-nitroaniline as a starting material [6]. The $p$-nitroaniline is widely used as an intermediate in various chemical reactions; therefore, its rate of reaction or reactivity is crucial. Previously published report suggested that reaction kinetics of any chemical reaction depend on the physical and thermal properties of intermediate compounds i.e., latent heat of fusion, and vaporization temperature etc. $[7,8]$. Hence, it is advantageous to find out an alternate approach, which could alter the physical, thermal and spectral properties of chemical compounds. Recently, several studies have been reported on biofield treatment to alter the spectral properties of various pharmaceutical drugs like metronidazole, tinidazole, paracetamol, and piroxicam; and physical, and structural properties of various metals i.e., tin, lead etc. [9-11]. The relation between mass-energy $\left(E=m c^{2}\right)$ was described by Einstein [12]. Furthermore, the energy exists in various forms and there are several ways to transfer the energy from one place to another such as electromagnetic waves, electrochemical, electrical and thermal etc. Similarly, the human nervous system consists of neurons, which have the ability to transmit information and energy in the form of electrical signals $[13,14]$. Thus, the human has the ability of energy harness from the environment or Universe and transmit this energy into any object (living or nonliving) on the Globe. The object(s) always receive the energy and responding into useful way, this process is known as biofield treatment or healing [15]. The National Center for Complementary and Alternative Medicine (NCCAM) considered this biofield treatment (therapy) in subcategory of energy therapies [16]. Mr. Trivedi's unique biofield energy is also known as biofield treatment (The Trivedi Effect $\rightarrow$ ). This effect is known to change the physicochemical, thermal and structural properties of metals [11,17] and ceramics [18]. Considerable changes in overall growth and yield of medicinal and agricultural plants were also reported after biofield treatment [19]. Further, biofield treatment has substantially altered the antimicrobial susceptibility, biochemical reactions pattern, and biotype number of several pathogenic microbes $[20,21]$. Conceiving the impact of biofield treatment on various living and nonliving things, the study was aimed to evaluate the impact of biofield treatment on spectral and physicochemical properties of $p$-nitroaniline. The effects were analyzed in both control and treated $p$-nitroaniline samples using Fourier transform infrared (FT-IR) spectroscopic, ultraviolet-visible (UV-Vis) spectroscopy, high performance liquid chromatography (HPLC), gas chromatography-mass spectrometry (GC-MS), and differential scanning calorimetry (DSC).

\section{Materials and Methods}

\section{Study design}

The $p$-nitroaniline was procured from Sigma-Aldrich, Mumbai, India. The study was performed in two groups of $p$-nitroaniline i.e., control and treatment. The control sample was named as untreated, and treatment sample was handed over in sealed pack to Mr. Trivedi for biofield treatment under laboratory condition. Mr. Trivedi provided this treatment through his energy transmission process to the treatment group without touching the sample [10]. The control and treated samples of $p$-nitroaniline (Figure 1) were evaluated using various analytical techniques viz. FT-IR, UV-Vis, HPLC, GC-MS, and DSC.

\section{FT-IR spectroscopic characterization}

FT-IR spectra of control and treated samples of $p$-nitroaniline were recorded on Shimadzu's Fourier transform infrared spectrometer (Japan) with frequency range of $4000-500 \mathrm{~cm}^{-1}$. The analysis was carried out to evaluate the impact of biofield treatment at atomic level like dipole moment, force constant and bond strength in chemical structure [22].

\section{UV-Vis spectroscopic analysis}

UV spectra of control and treated samples of $p$-nitroaniline were recorded on Shimadzu UV-2400 PC series spectrophotometer with $1 \mathrm{~cm}$ quartz cell and a slit width of $2.0 \mathrm{~nm}$. The analysis was carried out using wavelength in the range of $200-400 \mathrm{~nm}$. The UV spectral analysis was performed to determine the effect of biofield treatment on the energy gap of bonding and nonbonding transition of electrons [22].
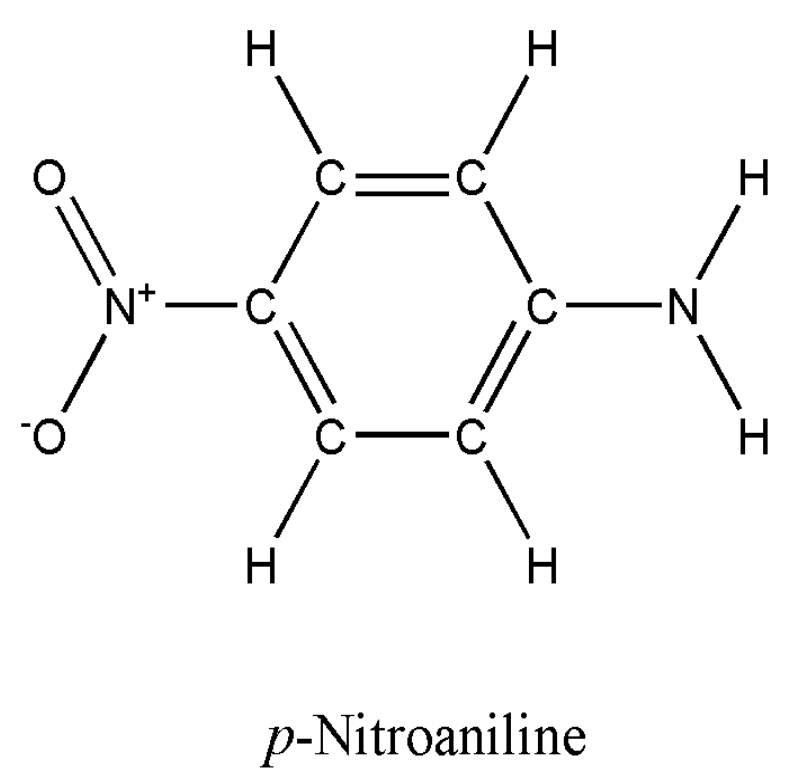

Figure 1 Chemical structure of $p$-nitroaniline. 


\section{HPLC analysis}

HPLC analysis of control and treated samples of $p$-nitroaniline were carried out on KNAUER's Smartline series of HPLC (Berlin, Germany) with Smartline pump 1000 and UV 2600 detector. The separation was carried out on Eurospher $100-\mathrm{C}_{18}$ column $(250 \times 4$ $\mathrm{mm}$ ) using methanol as a mobile phase. The analysis was carried out to evaluate the impact of biofield treatment on the purity and retention time $\left(\tau_{p}\right)$ of $p$-nitroaniline with respect to control. Alteration in retention time of analyte in identical HPLC conditions refers to changes in the polarity of analyte.

\section{Gas chromatography-mass spectroscopy (GC- MS) analysis}

The $p$-nitroaniline sample was divided into four groups: one was set as control and another three were coded as treatment i.e., T1, T2, and T3. The GC-MS analysis of control and treatment samples of $p$-nitroaniline was performed on Perkin Elmer/auto system XL with Turbo mass and electron ionization mode, USA. Detection limit was set up to 1 pico gram, and mass range was set to 10-650 amu. The isotopic ratio ${ }^{13} \mathrm{C} /{ }^{12} \mathrm{C}$ was expressed by its deviation in treated $p$-nitroaniline sample with respect to control. The isotopic abundances of ${ }^{13} \mathrm{C}$ and ${ }^{18} \mathrm{O}$ were computed on a delta scale per thousand. The values of $\delta^{13} \mathrm{C}$ and $\delta^{18} \mathrm{O}$ of treated samples were calculated using following equation.

$$
\delta^{18} \mathrm{O} \text { or } \delta^{13} \mathrm{C}(\% \mathrm{o})=\frac{\mathrm{R}_{\text {Treated }}-\mathrm{R}_{\text {Control }}}{\mathrm{R}_{\text {Control }}} \times 1000
$$

Where, $R_{\text {Treated }}$ and $R_{\text {control }}$ are the ratio of intensity at $m / z=139 / m /$ $z=138$ for $\delta^{13} \mathrm{C}$, and $\mathrm{m} / \mathrm{z}=140 / \mathrm{m} / \mathrm{z}=138$ for $\delta^{18} \mathrm{O}$ in mass spectra of treated and control samples respectively.

\section{Differential scanning calorimetry (DSC) analysis}

The control and treatment samples of $p$-nitroaniline were analyzed by using a Pyris- 6 Perkin Elmer DSC on a heating rate of $10^{\circ} \mathrm{C} / \mathrm{min}$ under air atmosphere and air was flushed at a flow rate of $5 \mathrm{~mL} / \mathrm{min}$. Percent change in latent heat of fusion was calculated using following equations:

$\%$ Change in Latent heat of fusion $=\frac{\left[\Delta \mathrm{H}_{\text {Treated }}-\Delta \mathrm{H}_{\text {Control }}\right]}{\Delta \mathrm{H}_{\text {Control }}} \times 100$

Where, $\Delta \mathrm{H}_{\text {control }}$ and $\Delta \mathrm{H}_{\text {Treated }}$ are the latent heat of fusion of control and treated samples, respectively.

\section{Results and Discussion}

\section{FT-IR spectroscopic analysis}

Vibrational spectral assignment was performed on the recorded FT-IR spectra (Figure $\mathbf{2} \mathbf{a}$ and $\mathbf{2}$ b) based on theoretically predicted wavenumber and presented in Table 1 . The $p$-nitroaniline has one $\mathrm{NH}_{2}$ group therefore one symmetric and one asymmetric $\mathrm{N}-\mathrm{H}$ stretching vibrations are expected that were assigned to peaks appeared in the region of $3350-3478 \mathrm{~cm}^{-1}$ in control and 3362 $3482 \mathrm{~cm}^{-1}$ in treated sample. It showed the upstream shifting of wavenumber of $\mathrm{N}-\mathrm{H}$ bond in treated sample with respect of control. The frequency $(v)$ or wavenumber of stretching vibrational
Table 1 FT-IR vibrational peaks observed in $p$-nitroaniline.

\begin{tabular}{|c|c|c|}
\hline \multicolumn{2}{|c|}{ Wave number $\left(\mathrm{cm}^{-1}\right)$} & \multirow{2}{*}{ Frequency assigned to } \\
\hline Control & Treated & \\
\hline $3350-3478$ & $3362-3482$ & $\mathrm{~N}-\mathrm{H}$ stretching \\
\hline 1628 & 1630 & $\mathrm{~N}-\mathrm{H}$ bending \\
\hline 1570 & 1585 & $\mathrm{C}=\mathrm{C}$ stretching \\
\hline 1507 & 1506 & $\begin{array}{c}\mathrm{N}=\mathrm{O}\left(\mathrm{NO}_{2}\right) \text { asymmetric } \\
\text { stretching }\end{array}$ \\
\hline 1430 & 1445 & $\mathrm{C}-\mathrm{C}$ stretching \\
\hline 1345 & 1344 & $\begin{array}{c}\mathrm{N}=\mathrm{O}\left(\mathrm{NO}_{2}\right) \text { asymmetric } \\
\text { stretching }\end{array}$ \\
\hline $1244-1283$ & $1300-1335$ & C-N stretching (aryl) \\
\hline $1103-1174$ & $1113-1183$ & $\begin{array}{c}\text { In plane aromatic } \mathrm{C}-\mathrm{H} \\
\text { deformation }\end{array}$ \\
\hline $664-779$ & $633-842$ & $\begin{array}{l}\text { Out of plane aromatic } \\
\mathrm{C}-\mathrm{H} \text { deformation and } \\
\text { in plane } \mathrm{C}-\mathrm{C}-\mathrm{C} \text { bending }\end{array}$ \\
\hline
\end{tabular}

peak depends on two factors i.e., force constant (k) and reduced mass $(\mu)$, which can be explained by following equation [23].

$v=1 / 2 \pi c v(k / \mu)$; here, $c$ is speed of light.

If $\mu$ is constant, then the frequency is directly proportional to the force constant; therefore, increase or decrease in frequency of any bond indicates a corresponding increase and decrease in force constant [22]. Based on this, it is speculated that the increased in wavenumber of $\mathrm{N}-\mathrm{H}$ bond after biofield treatment might be observed due to increased force constant of respective bond as compared to control. In addition to $\mathrm{N}-\mathrm{H}$ stretching, the $\mathrm{NH}_{2}$ group also has scissoring, rocking wagging and torsion modes of fundamental vibrations [2]. The $\mathrm{NH}_{2}$ scissoring vibrational mode was assigned to peak appeared at $1628 \mathrm{~cm}^{-1}$ in control and 1630 $\mathrm{cm}^{-1}$ in treated sample of $p$-nitroaniline. Theoretically, rest of $\mathrm{NH}_{2}$ group vibrations should appeared below $500 \mathrm{~cm}^{-1}$ that were not recorded in the spectra (Figure 2). The asymmetric vibration of $\mathrm{NO}_{2}$ group was assigned to peaks observed at $1507 \mathrm{~cm}^{-1}$ and $1506 \mathrm{~cm}^{-1}$ in control and treated sample, respectively. Likely the symmetric vibration of $\mathrm{NO}_{2}$ group was assigned to peak observed at $1345 \mathrm{~cm}^{-1}$ and $1344 \mathrm{~cm}^{-1}$, in control and treated sample respectively. The result showed that both the $\mathrm{N}-\mathrm{H}$ bending and $\mathrm{NO}_{2}$ asymmetric-symmetric vibrations in control and treated samples were observed in the similar frequency region. However, the FT-IR spectrum of treated sample showed the enhanced intensity of $\mathrm{NO}_{2}$ symmetric peak with respect to control. The existing literature on FT-IR suggested that intensity of vibrational peak of particular bond depends on ratio of change in dipole moment $(\partial \mu)$ to change in bond distance $(\partial r)$ i.e., the intensity is directly proportional to change in dipole moment and inversely proportional to change in bond distance [24]. Based on this, it is speculated that the increase in intensity of $\mathrm{NO}_{2}$ symmetric stretching in treated sample might be due to alteration in the ratio of $\partial \mu / \partial r$ as compared to control. The $\mathrm{C}=\mathrm{C}$ (aromatic) stretching was attributed to vibrational peak appeared at 1570 $\mathrm{cm}^{-1}$ and $1585 \mathrm{~cm}^{-1}$ in control and treated sample, respectively. Likewise, the $\mathrm{C}-\mathrm{C}$ stretching was assigned to peak appeared at $1430 \mathrm{~cm}^{-1}$ in control and $1445 \mathrm{~cm}^{-1}$ in treated sample. The result showed that both $\mathrm{C}=\mathrm{C}$ and $\mathrm{C}-\mathrm{C}$ stretching vibrations were shifted to higher wavenumber in treated sample with respect to control. 

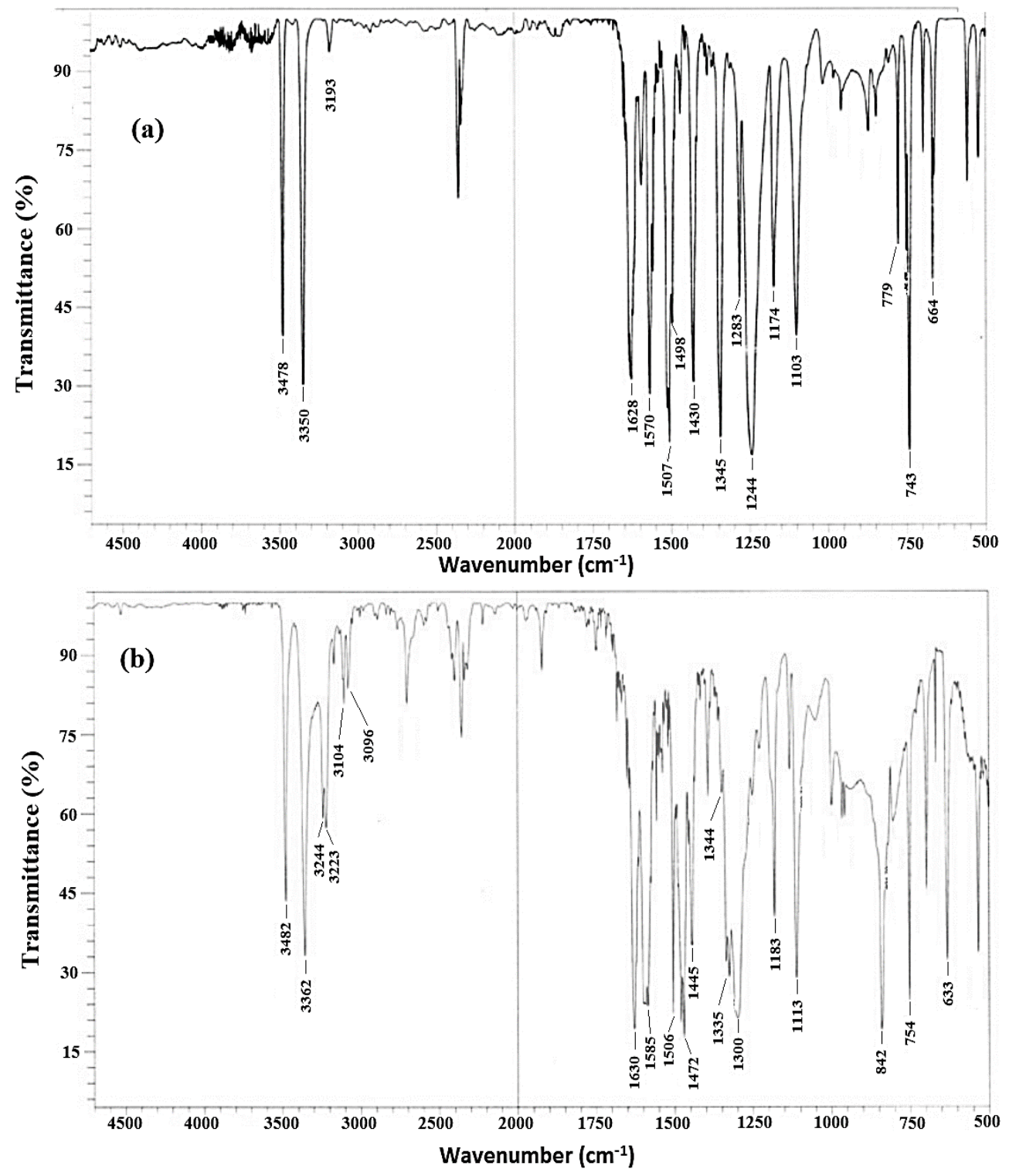

Figure 2 FT-IR spectra of $p$-nitroaniline (a) control and (b) treated.

This might be due to induced force constant and bond strength of respective bonds in treated sample with respect to control. The C-N stretching vibrations mode were assigned to peaks observed at $1244-1283 \mathrm{~cm}^{-1}$ in control and $1300-1335 \mathrm{~cm}^{-1}$ in treated sample. Further the $\mathrm{C}-\mathrm{H}$ in plane bendings were assigned to peak at 1103$1174 \mathrm{~cm}^{-1}$ and $1113-1183 \mathrm{~cm}^{-1}$ in control and treated sample respectively. The increase in wavenumber of $\mathrm{C}-\mathrm{N}$ stretching and $\mathrm{C}-\mathrm{H}$ in plane bending after biofield treatment depicted an increase in force constant and torsional force, respectively due to influence of biofield treatment. The out of plane $\mathrm{C}-\mathrm{H}$ bending peaks were assigned at 664-779 and 633-842 $\mathrm{cm}^{-1}$ in control and treated sample, respectively that also showed the biofield induced alteration in the wavenumber as compared to control. All together, the FT-IR data showed a significant change in the wavenumber and intensity of some bonds in treated sample with respect to control. This could be due alteration in force constant, dipole moment and bond length of respective bonds as compared to control.

\section{UV-Vis spectroscopy}

UV spectral analysis of control $p$-nitroaniline showed absorbance maxima $\left(\lambda_{\max }\right)$ at 226.4 and $359.6 \mathrm{~nm}$, which was also supported by the literature data [25]. After biofield treatment, the absorbance maxima $\left(\lambda_{\max }\right)$ values were slightly shifted at 228.0 $\mathrm{nm}$ and $362.0 \mathrm{~nm}$ in treated sample. The result showed the slight bathochromic shift in both the absorption peaks $\left(\lambda_{\max }\right)$ in treated sample. The compound can absorbs UV light due to the presence of either or both conjugated pi $(\pi)$-bonding systems ( $\pi-\pi^{*}$ transition) and nonbonding electron system ( $n-\pi^{*}$ transition). There is certain energy gap between $\pi-\pi^{*}$ and $n-\pi^{*}$ orbitals. When this energy gap altered, the wavelength $\left(\lambda_{\max }\right)$ was also altered respectively [22]. However, the UV study showed the similar pattern of absorbance maxima in both control and treated samples of $p$-nitroaniline. Based on this, it is speculated that, biofield treatment did not alter the energy gap between $\pi-\pi^{*}$ and $n-\pi^{*}$ transition in $p$-nitroaniline. 


\section{HPLC analysis}

The HPLC chromatogram of control and treated $p$-nitroaniline are shown in Figure 3. The HPLC chromatogram of control $p$-nitroaniline exhibited the corresponding peak at $2.75 \mathrm{~min}$ (Figure 3a), while the treated $p$-nitroaniline peak was observed at $3.25 \mathrm{~min}$ (Figure $\mathbf{3 b}$ ). The position of peak corresponding to analyte in the HPLC chromatogram depends on its polarity. In reverse phase HPLC, if the retention time increases in the same experimental condition, it suggests the increases in nonpolar property of respective analyte. Similarly, the decrease in retention time suggests an increase in polar property in the corresponding analyte sample [26]. The FT-IR spectral analysis suggested that biofield treatment has induced alteration in dipole moment of treated $p$-nitroaniline. Dipole moment can be referred to polarity in the molecule, therefore alteration in dipole moment can lead to alteration in the polarity, which could be seen in the HPLC analysis (retention time) result. Herein, we also observed a significant increase in the retention time of $p$-nitroaniline in treated sample as compared to control, which suggested that after biofield treatment some nonpolar property might be induced in $p$-nitroaniline with respect to control.

\section{GC-MS analysis}

The GC-MS spectra of control and treated (T1, T2, and T3) $p$-nitroaniline are shown in Figure $\mathbf{4 a}$ and $\mathbf{4 b}$, and the peak intensity of most probable isotopes are illustrated in Table $\mathbf{2}$. The GC-MS spectra of control and treated samples showed the primary molecule (PM, $p$-nitroaniline) peak at $m / z 138$ suggest the molecular weight of $p$-nitroaniline. In addition the peaks at $m / z 139$ and $m / z 140$ were assigned to isotopic abundance peaks due to $\mathrm{PM}^{+1}$ and $\mathrm{PM}^{+2}$ isotopes of $p$-nitroaniline [27]. It is well known that ${ }^{13} \mathrm{C}$ and ${ }^{18} \mathrm{O}$ isotope are more stable and exist in higher percentage than the ${ }^{3} \mathrm{H},{ }^{2} \mathrm{H},{ }^{15} \mathrm{~N}$, and ${ }^{17} \mathrm{O}$ isotopes. Therefore, it is presumed that isotopic abundance ratio of $\mathrm{PM}^{+1}$ is mainly due to ${ }^{13} \mathrm{C}$ and $\mathrm{PM}^{+2}$ is may be due to ${ }^{18} \mathrm{O}$ isotope in $p$-nitroaniline. Based on this it is speculated that the peak at $m / z 138$ is mainly due to ${ }^{12} \mathrm{C}_{6}{ }^{1} \mathrm{H}_{6}{ }^{14} \mathrm{~N}_{2}{ }^{16} \mathrm{O}_{2}, \mathrm{~m} / z 139$ is due to ${ }^{13} \mathrm{C}_{1}{ }^{12} \mathrm{C}_{5}{ }^{1} \mathrm{H}_{6}{ }^{14} \mathrm{~N}_{2}{ }^{16} \mathrm{O}_{2}$ and $m / z 140$ is due to ${ }^{12} \mathrm{C}_{6}{ }_{6} \mathrm{H}_{6}{ }^{14} \mathrm{~N}_{2}{ }^{18} \mathrm{O}_{1}{ }^{16} \mathrm{O}_{1}$. The GCMS analysis result (Table 2) suggested that the isotopic abundance of ${ }^{13} \mathrm{C}\left(\delta^{13} \mathrm{C}\right)$ was changed as $-23.33,-63.31$, and $-30.15 \%$ o in $\mathrm{T} 1, \mathrm{~T} 2$, and $\mathrm{T} 3$, respectively; and the isotopic abundance of ${ }^{18} \mathrm{O}\left(\delta^{18} \mathrm{O}\right)$ was changed as $-8.22,-56.54$, and $-44.43 \%$ o in $\mathrm{T} 1, \mathrm{~T} 2$, and $\mathrm{T} 3$, respectively as compared to control. The result depicted that in all the treated sample the ${ }^{13} \mathrm{C}$ and ${ }^{18} \mathrm{O}$ were transformed into ${ }^{12} \mathrm{C}$ and ${ }^{16} \mathrm{O}$, respectively by releasing the neutron(s) (one from ${ }^{13} \mathrm{C}$ and two from ${ }^{18} \mathrm{O}$ ). This inter-conversion of ${ }^{13} \mathrm{C}-{ }^{12} \mathrm{C}$, and ${ }^{18} \mathrm{O}-{ }^{16} \mathrm{O}$ might possible if a nuclear level reaction occurred due to influence of biofield treatment. Based on this, it is postulated that biofield treatment possibly induced the nuclear level reactions in $p$-nitroaniline, which may lead to convert the ${ }^{13} \mathrm{C}$ and ${ }^{18} \mathrm{O}$ into ${ }^{12} \mathrm{C}$ and ${ }^{16} \mathrm{O}$, respectively.
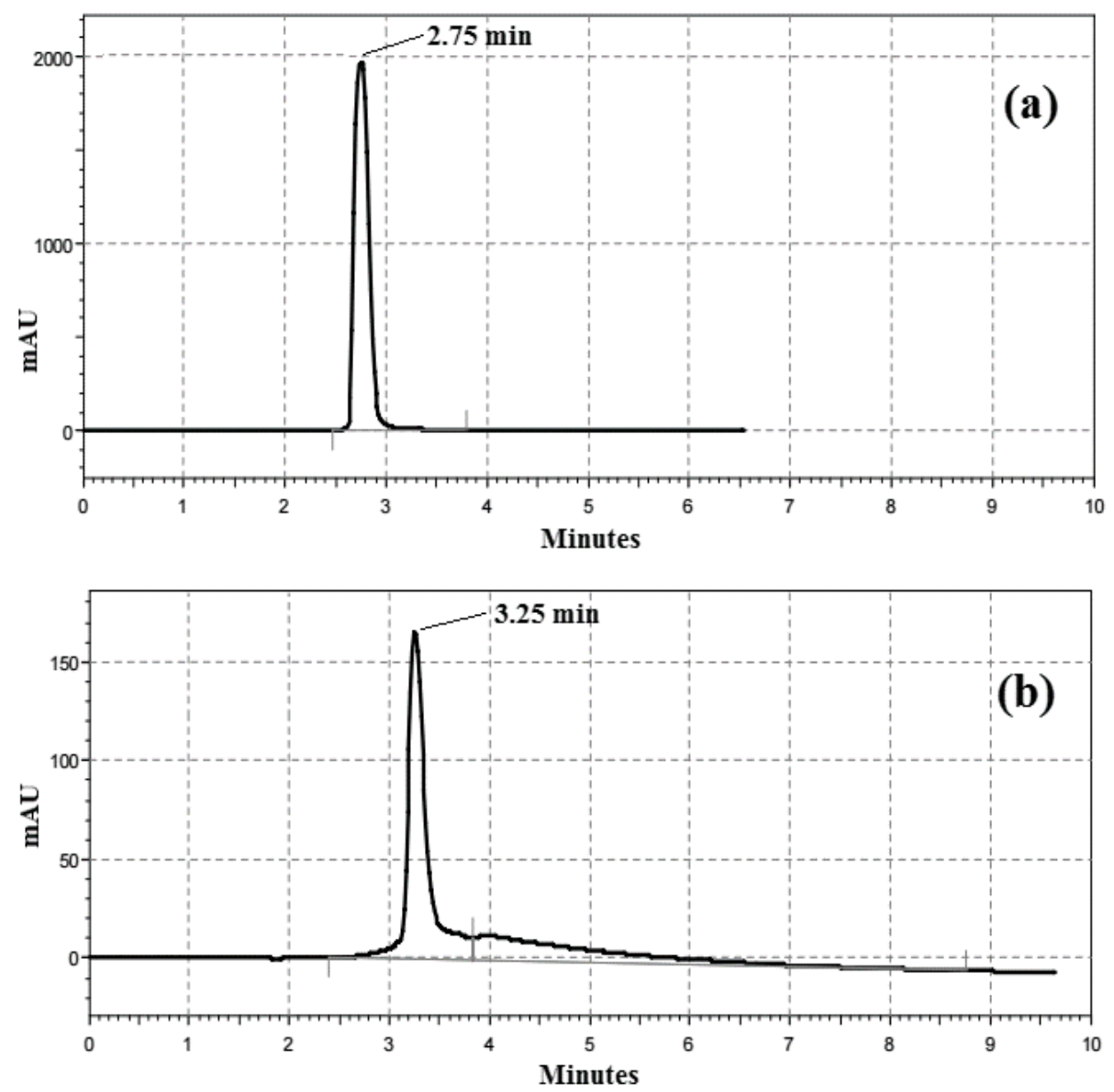

Figure 3 HPLC chromatogram of $p$-nitroaniline (a) control and (b) treated. 

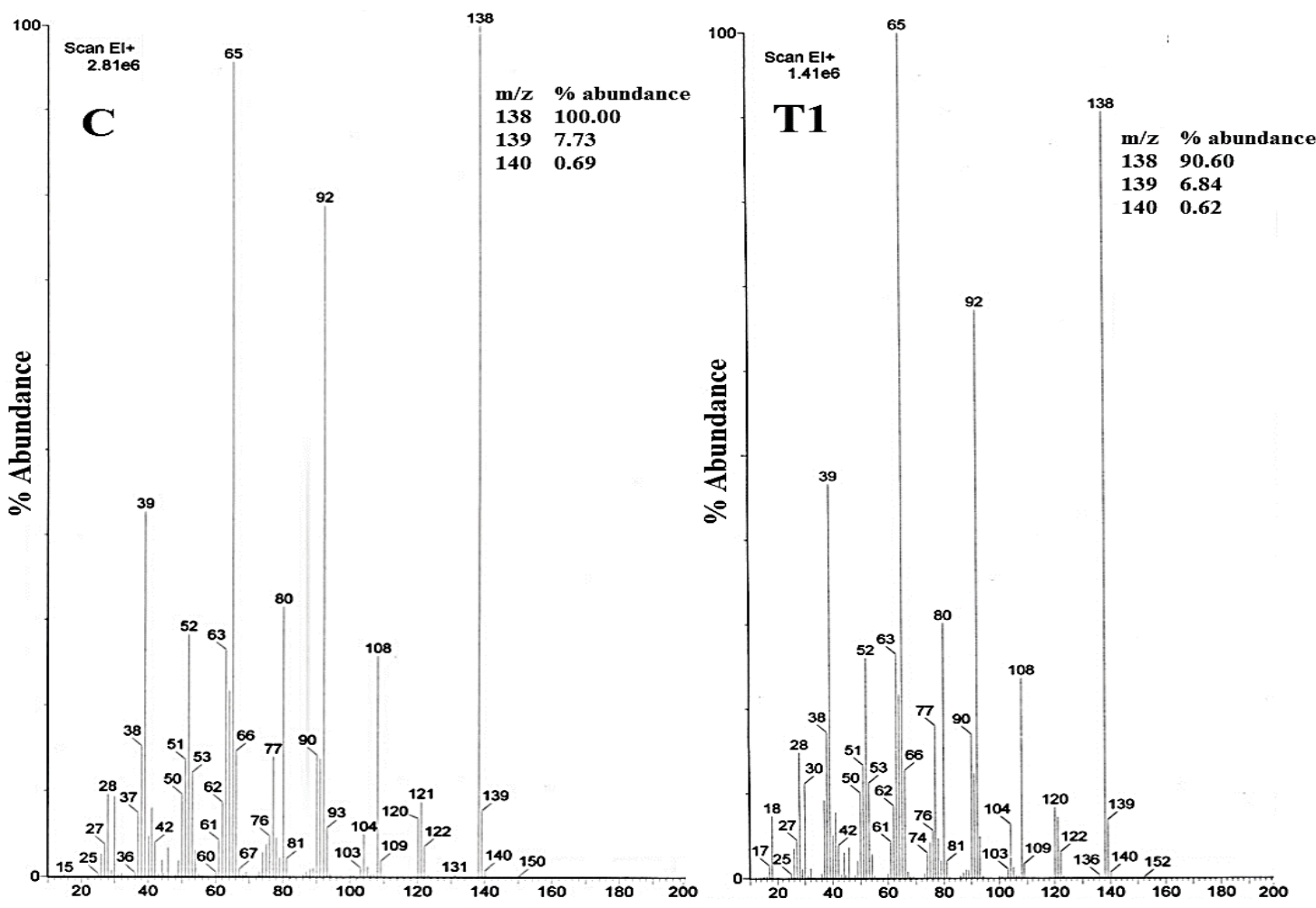

Figure 4a GC-MS spectra of $p$-nitroaniline (c) control and (T1) treated.
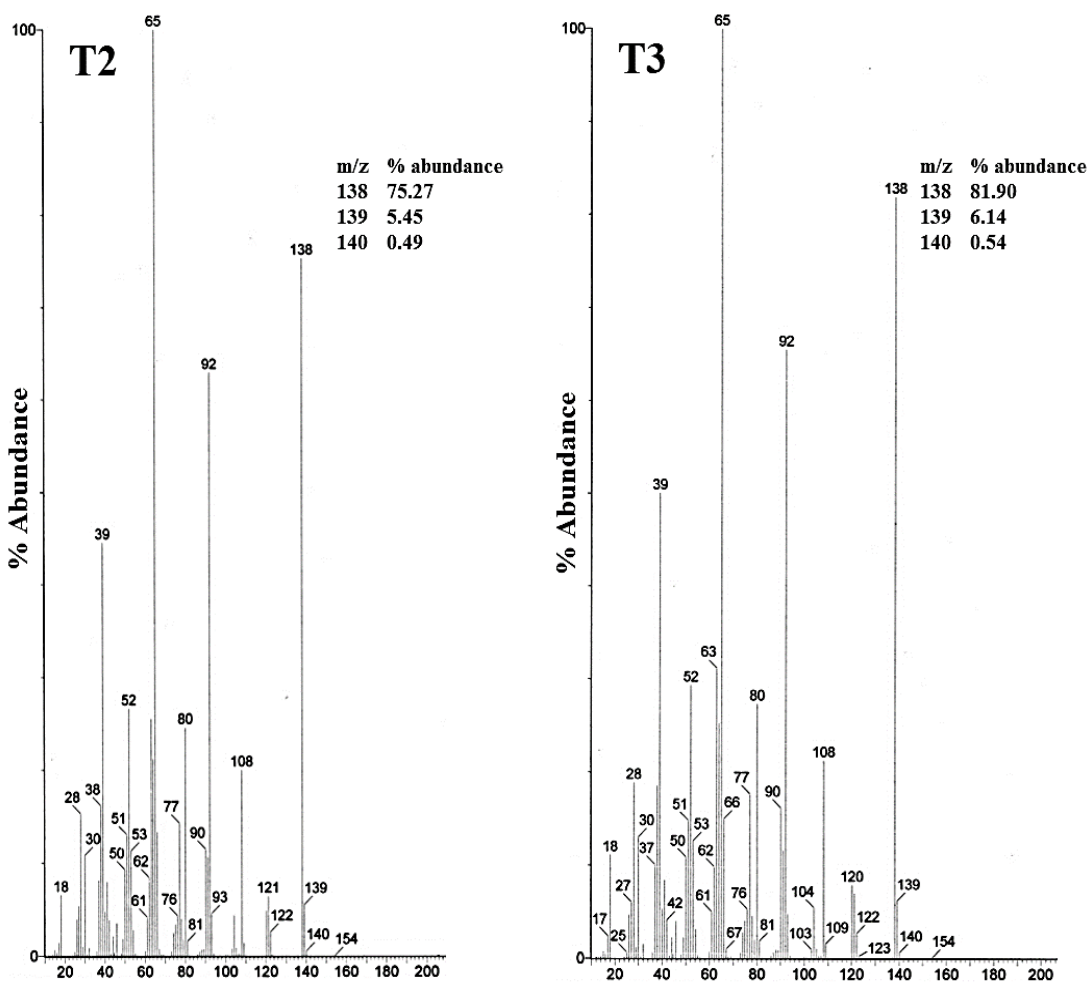

Figure 4b GC-MS spectra of treated sample of $p$-nitroaniline (T2 and T3). 
Table 2 GC-MS isotopic abundance analysis of $p$-nitroaniline. PM: primary molecule ( $p$-nitroaniline).

\begin{tabular}{|c|c|c|c|c|}
\hline \multirow{2}{*}{ Parameter } & \multirow{2}{*}{ Control } & \multicolumn{3}{|c|}{ Treated } \\
\hline & & T1 & T2 & T3 \\
\hline $\begin{array}{l}\text { Peak intensity at } m / z=138 \\
\text { (PM) }\end{array}$ & 100 & 90.60 & 75.27 & 81.90 \\
\hline $\begin{array}{l}\text { Peak intensity at } m / z=139 \\
\qquad\left(\mathrm{PM}^{+1}\right)\end{array}$ & 7.73 & 6.84 & 5.45 & 6.14 \\
\hline $\begin{array}{l}\text { Peak intensity at } m / z=140 \\
\qquad\left(\mathrm{PM}^{+2}\right)\end{array}$ & 0.69 & 0.62 & 0.49 & 0.54 \\
\hline${ }^{13} \mathrm{C}=100 \times\left(\mathrm{PM}^{+1} / \mathrm{PM}\right)$ & 7.730 & 7.550 & 7.241 & 7.497 \\
\hline $\begin{array}{c}\text { Isotopic abundance, } \delta^{13} \mathrm{C} \\
(\%)\end{array}$ & & -23.33 & -63.31 & -30.15 \\
\hline${ }^{18} \mathrm{O}=100 \times\left(\mathrm{PM}^{+2} / \mathrm{PM}\right)$ & 0.690 & 0.684 & 0.651 & 0.659 \\
\hline $\begin{array}{c}\text { Isotopic abundance, } \delta^{18} \mathrm{O} \\
(\%)\end{array}$ & & -8.22 & -56.54 & -44.43 \\
\hline
\end{tabular}

\section{DSC study}

DSC was used to analyze the melting temperature and latent heat of fusion $(\Delta \mathrm{H})$ of control and treated $p$-nitroaniline. The DSC thermogram of control and treated $p$-nitroaniline are shown in Figure 5. In a solid content, substantial amount of interaction force exists in atomic bonds that hold the atoms at their positions. $\Delta \mathrm{H}$ can be defined as the energy required to overcome this interaction force to change the phase from solid to liquid. Hence, the energy provided during phase change i.e., $\Delta \mathrm{H}$ is stored as potential energy of atoms. However, melting point is related to kinetic energy of the atoms [28]. The DSC thermogram showed the melting temperature at $149.31^{\circ} \mathrm{C}$ for control and $149.18^{\circ} \mathrm{C}$ for treated sample, which revealed the similar melting point in control and treated sample of $p$-nitroaniline. The melting temperature of $p$-nitroaniline is well supported by literature data [29]. The DSC thermogram showed the $142.92 \mathrm{~J} / \mathrm{g}$ latent heat of fusion $(\Delta \mathrm{H})$ in treated sample and $159.98 \mathrm{~J} / \mathrm{g}$ in control sample. The result showed decrease in latent heat of fusion in treated p-nitroaniline by $10.66 \%$ in comparison with control. It may be due to conversion of $p$-nitroaniline to lower energy state (lower potential energy) after biofield treatment. Previously, our group has been reported that biofield treatment has shown alteration in latent heat of fusion of lead and tin powders [11]. Therefore, it is assumed that biofield treatment might alter the potential energy of treated $p$-nitroaniline that may lead to change the latent heat of fusion.

\section{Conclusion}

FT-IR spectrum of treated $p$-nitroaniline showed the alteration in wavenumber of IR peaks assigned to $\mathrm{N}-\mathrm{H}, \mathrm{C}=\mathrm{C}, \mathrm{C}-\mathrm{C}$ stretching, and $\mathrm{C}-\mathrm{H}$ deformation vibrations. This is might be occurred due to alteration in the dipole moment and force constant of the respective bond in treated sample as compared to the control.
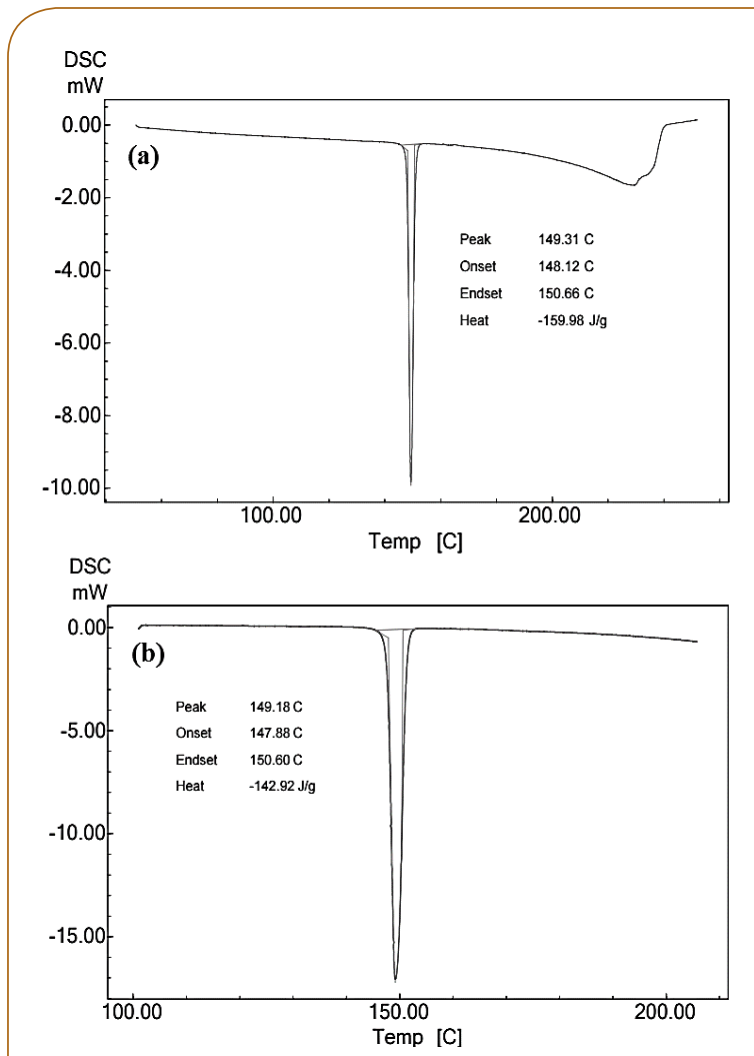

Figure 5 DSC thermogram of $p$-nitroaniline (a) control and (b) treated.

HPLC chromatogram showed an alteration in the retention time of $p$-nitroaniline peak with respect to control, which is possibly due to alteration in the polarity of treated sample as compared to the control. The GC-MS analysis showed that isotopic abundance of ${ }^{13} \mathrm{C}\left(\delta^{13} \mathrm{C}\right)$ was altered about $-23.33,-63.31$, and $30.15 \%$ in $\mathrm{T} 1, \mathrm{~T} 2$, and T3, respectively; whereas. The $\delta^{18} \mathrm{O}$ was altered about -8.22 , -56.54 , and $-44.43 \%$ in $\mathrm{T} 1, \mathrm{~T} 2$, and $\mathrm{T} 3$, respectively. This might be occurred due to the biofield energy mediated changes at nuclear level reaction in the treated sample. The DSC analysis showed the considerable change (10.66\%) in latent heat of fusion in treated sample as compared to control. It may be due to transformation of $p$-nitroaniline to lower energy state after biofield treatment. Altogether, the FT-IR, HPLC, GC-MS and DSC results suggest that biofield treatment has significant effect on structural, physical and thermal properties of biofield treated $p$-nitroaniline with respect to control sample. This might be corroborated to possible changes in chemical and thermal stability of treated $p$-nitroaniline.

\section{Acknowledgements}

The authors would like to acknowledge the whole team of MGV pharmacy college, Nashik for providing the instrumental facility. We would also like to thank Trivedi science, Trivedi master wellness and Trivedi testimonials for their support during the work. 


\section{References}

1 Travis AS (2007) Manufacture and uses of the anilines: A vast array of processes and products, the chemistry of anilines. The chemistry of functional groups, Wiley, New York.

2 Kavitha E, Sundaraganesan N, Sebastin S (2010) Molecular structure, vibrational spectroscopic and HOMO, LUMO studies of 4-nitroaniline by density functional method. Indian J Pure Appl Phys 48: 20-30.

3 Shanker V, Rayabandla SM, Kumavath RN, Chintalapati S, Chintalapati $\mathrm{R}$, et al. (2006) Light-dependent transformation of aniline to indole esters by the purple bacterium Rhodobacter sphaeroides OU5. Curr Microbiol 52: 413-417.

4 Patel SR (2012) Study of the photosensitized reaction of the isomeric fluoroanilines with methylene blue in the visible light.

5 Himaja M, Das P, Rout PK, Sharma S, Munirajasekhar D, et al. (2012) Synthesis docking and antioxidant activity of some NSAID derivatives of amines. Int J Res Ayurveda Pharm 3: 548-551.

6 Fierz-David HE, Blangey L (1949) Fundamental processes of dye chemistry. 5th edn, Interscience publishers, New York.

7 Carballo LM, Wolf EE (1978) Crystallite size effects during the catalytic oxidation of propylene on $\mathrm{Pt} / \mathrm{\Upsilon}-\mathrm{Al}_{2} \mathrm{O}_{3}$. J Catal 53: 366-373.

8 Chaudhary AL, Sheppard DA, Paskevicius M, Pistidda C, Dornheim M, et al. (2015) Reaction kinetic behaviour with relation to crystallite/grain size dependency in the Mg-Si-H system. Acta Mater 95: 244-253.

9 Trivedi MK, Patil S, Shettigar H, Bairwa K, Jana S, et al. (2015) Spectroscopic characterization of biofield treated metronidazole and tinidazole. Med Chem 5: 340-344.

10 Trivedi MK, Patil S, Shettigar H, Bairwa K, Jana S, et al. (2015) Effect of biofield treatment on spectral properties of paracetamol and piroxicam. Chem Sci J 6: 98.

11 Trivedi MK, Patil S, Tallapragada RM (2013) Effect of bio field treatment on the physical and thermal characteristics of silicon, tin and lead powders. J Material Sci Eng 2: 125.

12 Einstein A (1905) Does the inertia of a body depend upon its energycontent? Ann Phys 18: 639-641.

13 Becker RO, Selden G (1985) The body electric: Electromagnetism and the foundation of life. New York City, William Morrow and Company.

14 Planck M (1903) Treatise on thermodynamics. 3rd edn. English translated by Alexander OGG, Longmans, Green, London.

15 Aldridge D (1991) Spirituality, healing and medicine. Br J Gen Pract 41: 425-427.
16 Hök J, Tishelman C, Ploner A, Forss A, Falkenberg T (2008) Mapping patterns of complementary and alternative medicine use in cancer: an explorative cross-sectional study of individuals with reported positive "exceptional" experiences. BMC Complement Altern Med 8: 48.

17 Dabhade VV, Tallapragada RR, Trivedi MK (2009) Effect of external energy on atomic, crystalline and powder characteristics of antimony and bismuth powders. Bull Mater Sci 32: 471-479.

18 Trivedi MK, Patil S, Tallapragada RM (2014) Atomic, crystalline and powder characteristics of treated zirconia and silica powders. J Material Sci Eng 3: 144.

19 Nayak G, Altekar N (2015) Effect of biofield treatment on plant growth and adaptation. J Environ Health Sci 1: 1-9.

20 Trivedi MK, Bhardwaj Y, Patil S, Shettigar H, Bulbule A, et al. (2009) Impact of an external energy on Enterococcus faecalis [ATCC-51299] in relation to antibiotic susceptibility and biochemical reactions-an experimental study. J Accord Integr Med 5: 119-130.

21 Trivedi MK, Patil S, Shettigar H, Gangwar M, Jana S, et al. (2015) An effect of biofield treatment on multidrug-resistant Burkholderia cepacia: A multihost pathogen. J Trop Dis 3: 167.

22 Pavia DL, Lampman GM, Kriz GS (2001) Introduction to spectroscopy. 3rd edn, Thomson Learning, Singapore.

23 Stuart BH (2004) Infrared spectroscopy: Fundamentals and applications (analytical techniques in the sciences (AnTs)). John Wiley \& Sons, Chichester, UK.

24 Smith BC (1999) Infrared spectral interpretation: A systematic approach. CRC Press.

25 Costelaa A, Garcia-Moreno I, Dabriob J, Sastreb R (1997) Photophysics and photochemistry of $p$-nitroaniline as photoinitiator. J Photochem Photobiol A: Chem 109: 77-86.

26 Buszewski B1, Noga S (2012) Hydrophilic interaction liquid chromatography (HILIC)--a powerful separation technique. Anal Bioanal Chem 402: 231-247.

27 Bakdash A, Ganswindt M, Herre S, Nadulski T, Pragst F, et al. (2006) Lethal poisoning with p-nitroaniline. $T+K$ 73: 61-65.

28 Moore J (2010) Chemistry: The molecular science. 4th edn, Brooks Cole.

29 O'Neil MJ (2006) The Merck index - An encyclopedia of chemicals, drugs, and biologicals. Merck and Co., Inc. Whitehouse Station. 